\title{
Food Self-provisioning in Europe: An Exploration of Sociodemographic Factors in Five Regions*
}

\author{
Jan Vávra \\ Faculty of Economics \\ University of South Bohemia in České Budéjovice \\ Boldizsár Megyesi \\ Centre for Social Sciences \\ Hungarian Academy of Sciences \\ Barbora Duží \\ Department of Environmental Geography \\ Institute of Geomics, The Czech Academy of Sciences \\ Tony Craig \\ Social, Economic and Geographical Sciences Group \\ The James Hutton Institute \\ Renata Klufová \\ Faculty of Economics \\ University of South Bohemia in České Budéjovice \\ Miloslav Lapka \\ Faculty of Economics \\ University of South Bohemia in České Budéjovice \\ Eva Cudlínová \\ Faculty of Economics \\ University of South Bohemia in České Budéjovice
}

\footnotetext{
* We thank all the respondents who participated in the survey. Mary Grigsby, James S. Rikoon (both University of Missouri), Petr Jehlička (Open University, United Kingdom), and three anonymous reviewers contributed very valuable comments to previous versions of the article. We thank Justin Schaefer from the University of South Bohemia for correcting the English. Data were collected with support from the EU Seventh Framework Programme (FP7/2007-2013) under research project GILDED, grant agreement no. 225383. Jan Vávra and Eva Cudlínová would like to acknowledge the support of the project Postdoc USB (reg.no. CZ.1.07/2.3.00/30.0006) realized through the EU Education for Competitiveness Operational Programme and funded by the European Social Fund and Czech state budget. The work of Boldizsár Megyesi was supported by the Bolyai Postdoctoral Scholarship of the Hungarian Academy of Sciences and the Hungarian Scientific Research Fund (project no. PD 116219). Barbora Duží is very thankful for the support of the long-term conceptual development of the research organization (Institute of Geonics, The Czech Academy of Sciences), no. RVO 68145535. Tony Craig would like to acknowledge the support of the Scottish Government Rural Affairs, Food and the Environment Strategic Research Programme (WP 3.2, RD 4). Direct correspondence to Jan Vávra, Department of Regional Management, Faculty of Economics, University of South Bohemia in České Budějovice, Studentská 13, 37005 České Budějovice, Czech Republic, 420-389-032-760; e-mail: jvavra@ef.jcu.cz.
} 
Abstract This article presents the results of an international comparative study on food self-provisioning, an activity still widespread in the countries of the Global North. We collected the data in a sociological survey done in 2010 as a part of the household energy use research project GILDED. We selected a region with urban and rural areas as a case study in each of the five EU countries, including Scotland, the Netherlands, Germany, the Czech Republic, and Hungary. Our article raises two main research questions: (1) What is the level of food self-provisioning in the regions? (2) Who participates in it? Additionally, we inquired into the motivations of selfprovisioners using the results of analyses of sociodemographic and food consumption habits for their interpretation. We found that the level of selfprovisioning varies considerably among the regions. Its share ranges from 13 percent in Dutch urban areas to 58 percent in German rural areas. The effects of some sociodemographic and geographic factors differ significantly among the countries. However, we can summarize that living in one's own property, living in a house or in a rural area, having a partner or children, being retired, or having a low income increases the probability of food selfprovisioning.

\section{Introduction}

Production of one's own food was a typical activity of the majority of people throughout our agricultural history until the industrialization and urbanization in Europe and the United States in the nineteenth and twentieth centuries. By the second half of the twentieth century, the production of one's own food was no longer predominantly a domain of farming but a gardening activity. Food self-provisioning (at the gardening level) has become a mainstream topic among sustainability-oriented social scientists and rural sociologists in recent years (e.g., Jehlička and Smith 2011; Larder, Lyons, and Woolcock 2014; Schupp and Sharp 2012; Taylor and Lovell 2013; Teitelbaum and Beckley 2006).

However, despite the recent interest in food self-provisioning, Taylor and Lovell (2013) argue that in the Global North, home gardens are still often overlooked and underresearched. This lack of attention stands in contrast to the amount of research on community gardens in the Global North or the attention paid to home gardens in the Global South. In fact, there are both qualitative and quantitative studies on food self-provisioning, the latter including local cases and national representative surveys, although there have only been a few international comparative quantitative studies that raised the question of who is participating in food self-provisioning in the Global North.

Therefore, our research investigates the level of food selfprovisioning among various regions of the European Union (EU) and asks which sociodemographic, geographic, and behavioral factors 
influence participation in food self-provisioning. This article presents the results of our research conducted through a large quantitative sociological survey carried out in spring 2010 in the regions of five European countries: the United Kingdom (Scotland), the Netherlands, Germany, the Czech Republic, and Hungary, with 2,486 respondents. This crosscut through the European Union allows us to compare regions from EU states with different natural, climatic, economic, and social conditions and histories. The analyzed factors include sex, age, place of living, housing (type and ownership), education, income, and food consumption habits, and by using the outcomes of the statistical analysis, we also discuss the motivations behind food self-provisioning. The main method of statistical analysis we used is multiple logistic regression, calculated for the large international sample of respondents as well as for the five countries individually.

According to our definition, food self-provisioning is the growing of one's own food, especially fruits and vegetables, by people who are not professional farmers and mostly at a small-scale gardening level. Usually this will mean house gardens but it can also include allotment gardens, community gardens, gardens on a balcony or roof, or small-scale farming (see, e.g., Duží et al. 2014). It is an informal means of food production with the major part of it used for self-consumption. However, gardeners often share or exchange their surplus with family members and friends, or may occasionally sell it in informal or formal markets (Jehlička and Daněk forthcoming; Jehlička, Kostelecký, and Smith 2013; Kovách and Megyesi 2006). Furthermore, food self-provisioning is regarded as a longterm persistent practice, which is practiced both in rural and urban areas.

This article begins with a literature review, with a brief history of food self-provisioning as a home gardening activity followed by a review of the general context of food self-provisioning research. The review then moves on to more detailed subsections focusing on geographic, economic, and sociodemographic aspects before summarizing the cultural aspects and motivation for food self-provisioning and their links to food consumption choices. The literature review section is followed by a section on research questions and explanation of methods, which includes the description of the five regions, information about the sample of respondents, methods of data collection, and analysis. Some limitations of the research are also presented there. The following section merges the results and discussion, beginning with an international comparison followed by the results of individual regions and a detailed discussion of the effects of sociodemographic, economic, geographic, and food consumption factors. In conclusion, we summarize the results of the research and suggest potential topics for future research. 


\section{Literature Review}

The literature review focuses mainly on food self-provisioning in home gardens in the Global North, and excludes community gardening due to its rather different nature and the fact that community gardens have already been well researched and theorized (see, e.g., Taylor and Lovell 2013). For gardening in the Global South see, for example, Niñez (1984), Galhena, Freed, and Maredia (2013), or Taylor and Lovell (2013).

\section{History of Food Self-provisioning at the Gardening Level}

Small-scale food self-provisioning has a long tradition in many European countries and can also be found in the United States. To support the food security of the poor and improve their diet, allotment gardens were established in several cities throughout the nineteenth and twentieth centuries. One of the first examples can be found in Germany, where these small gardens are called Schrebergartens, after Moritz Schreber (Niñez 1984). Allotment gardens also have a long tradition rooted in the nineteenth century in the United Kingdom, Sweden, the Netherlands, Denmark, and Poland (Gibas et al. 2013). Many European countries supported the creation of allotment gardens between World War I and World War II to help improve the food security of the urban working class (Anne C. Bellows cited in Jehlička et al. 2013). Gardening and small-scale farming were also common in central and eastern Europe (a region mainly including countries with a communist history), for example, in the former Czechoslovakia, Hungary, or Poland, even before the communist regime and the collectivization of agriculture. It remained in practice during the communist period although there were differences among the countries. Food self-provisioning had a supplementary character in countries like Czechoslovakia and Hungary while it had been an important source of food in more "Stalinist" countries like Romania, Albania (Jehlička et al. 2013; Swain 2001), and the Soviet Union. This was often due to the failures of their production and distribution systems (e.g., Clarke et al. 2000; Rose and Tikhomirov 1993).

In the United States, gardening, as summarized by Schupp and Sharp (2012), was more often a hobby of the rich in the eighteenth century and its practice decreased during the nineteenth and twentieth centuries due to a lack of space in growing cities, market development, and the increased efficiency of the agricultural industry. However, even in industrialized countries such as the United States 
or United Kingdom, home gardens gained increased importance in times of crisis, leading to the so-called war gardens of World War I, relief gardens during the Great Depression, and victory gardens in World War II (Niñez 1984; Schupp and Sharp 2012). Food selfprovisioning as a traditional way of food production has never been entirely abandoned.

\section{General Context of Food Self-provisioning Research}

Current trends in academia often assess food self-provisioning as a traditional backward strategy of "urban peasants" in less developed countries or those going through transition periods (e.g., Alber and Kohler 2008; Rose and Tikhomirov 1993). In more developed countries it is seen as a neutral or positive trend and as a reflexive practice (Fonte 2013), as an area for social and gardening innovations (Duží et al. 2014), and as a practice of resistance (Larder et al. 2014; Van der Ploeg 2009). The importance for food security and nutrition has been emphasized (Galhena et al. 2013; Kortright and Wakefield 2011; Morton et al. 2008) as well as the potential of social inclusion and the strengthening of social and family networks and community development (Gray et al. 2014; Jehlička and Smith 2012; Larder et al. 2014; Torsello 2005). Apart from the economic motivation (e.g., Alber and Kohler 2008), the role of lifestyles, tradition, and leisure is increasingly being emphasized (Brown, Xu, and Toth 1998; Clarke et al. 2000; Domene and Saurí 2007; Jehlička et al. 2013). Additionally, there are positive health and psychological outcomes related to food self-provisioning (Domene and Saurí 2007; Gray et al. 2014; Kortright and Wakefield 2011).

Gardening also brings some positive environmental impacts such as an increase in biodiversity and species conservation (Calvet-Mir et al. 2011; Vogl and Vogl-Lukasser 2003), local air cooling (Cameron et al. 2012), and the lowering of greenhouse gas emissions from industrial food production, which contributes significantly to household carbon footprints (Schächtele and Hertle 2007; Vávra and Lapka 2013). Research done in the Czech Republic and Poland illustrates the positive environmental impacts as well. Most of the food self-provisioners mainly use natural fertilizers and do not need any vehicles to get to their garden (Smith and Jehlička 2013). There may be some negative environmental aspects, for example, the risk of overuse of pesticides and fertilizers (Dewaelheyns et al. 2013), but the research suggests that the positive ones predominate. 


\section{Geographic Patterns of Food Self-provisioning}

In the United States, an estimated 31 percent of households participate in some form of community food production, which in general includes home and community gardening (Bruce Butterfield cited in Smith, Greene, and Silbernagel 2013).

According to Alber and Kohler (2008), the rate of food selfprovisioning in 2003 ranged between 10 and 25 percent in long-term EU members (lowest in the Netherlands, highest in Luxembourg), ${ }^{1}$ while the number was significantly higher in postcommunist countries, ranging from approximately 30 percent in the Czech Republic ${ }^{2}$ to almost 60 percent in Slovakia. The situation was relatively dynamic in the postcommunist states. Rose and Tikhomirov (1993), for example, argue that in the early 1990s the rate of food self-provisioning was 70 percent in Czechoslovakia, 62 percent in Bulgaria, 48 percent in Poland, and even 72 percent in Russian cities (this includes people helping friends or relatives who grow food). Recent data for the Czech Republic indicates self-provisioning rates of 42 percent in 2005 and 43 percent in 2010, suggesting that the rate of food self-provisioning had stabilized after the decrease of the 1990s. The current percentage of food self-provisioners in Poland is 54 percent (Smith and Jehlička 2013). These numbers illustrate that food self-provisioning is a relatively widespread activity in many countries of the Global North.

In their Ohio-based study, Schupp and Sharp (2012) reported 48 percent of participants as having a garden and producing food. That said, some of the nonrepresentative characteristics of the sample may slightly increase the real number of food self-provisioners in the state. Food self-provisioning is common both in urban and rural areas. More than one-third of respondents (37 percent) in a case study of two neighborhoods in Toronto (Kortright and Wakefield 2011) grew fruits or vegetables. In rural Canada, 42 percent of respondents in one study said they grew some vegetables (Teitelbaum and Beckley 2006) although the number of consumers of nonpurchased vegetables (62 percent) suggests that a large part of the population is involved in food sharing. A similar share of people planting food in gardens (44 percent) was

\footnotetext{
${ }^{1}$ Although Luxembourg has one of the highest net average incomes per person in the EU, it had the highest share of food self-provisioning among the old EU members. This supports the importance of noneconomic factors.

${ }^{2}$ Given the dynamic of social change in the Czech Republic (and former Czechoslovakia), the number of around 30 percent in 2003 seems to be unrealistically low, compared to 42 percent in 2005 (Smith and Jehlička 2013). This raises the question of whether the rates of food self-provisioning are not undervalued also for other countries by Alber and Kohler (2008), who used the results of the European Quality of Life Survey in 2003.
} 
reported by Brown and colleagues (1998) from Mississippi Delta rural communities. The research comparing the differences in rural and urban areas shows rural populations usually participate more in food self-provisioning. In Ohio, food self-provisioning is generally more common in rural localities and even more so in households residing in the countryside or on farms. However, a significant share of people produce some food in the city cores (37 percent) or in metropolitan areas (42 percent) (Schupp and Sharp 2012).

In the Czech Republic, the rural-urban distinction is also important. In rural municipalities (less than 2,000 citizens), food selfprovisioning is carried out by 65 percent of inhabitants, in midsized towns it is 41 percent, and in the capital Prague (population over 1 million) it is only 21 percent. The difference is more significant in Poland, ranging from 74 percent of food self-provisioners in rural areas to 36 percent in cities of over 50,000 inhabitants (Smith and Jehlička 2013).

Although there are differences between rural and urban regions, we argue that these are mostly due to the greater likelihood of having a garden in rural areas. According to Schupp and Sharp (2012), residing in a detached house (linked with a greater likelihood of having a garden) is a much stronger predictor of food self-provisioning than any of the geographical indicators.

According to Rose and Tikhomirov (1993), living in rural areas significantly increased the probability of food self-provisioning in Poland, Bulgaria, and the former Czechoslovakia, although the share of food self-provisioning was more than 50 percent of the population even in the large cities. The most important explaining factor for food selfprovisioning was access to land, suggesting that those who had the possibility to produce food did. Yet we must stress that the political and economic situation has changed in the intervening period between the start of the transformation of the early 1990 s and the time that our current research was carried out.

\section{Economic Interpretation}

The economic point of view on food self-provisioning can be applied at the level of countries as well as the level of households or individuals. Alber and Kohler (2008) used European data (see above) showing that food self-provisioning is more common in former communist states to argue that it is a coping strategy of the poor in postcommunist states (urban peasantry), while it is a hobby or recreational activity in affluent 
countries. Such "modernistic" views can especially be found in studies of Russia's transformation of the 1990s.

Rose and Tikhomirov (1993) and tho Seeth et al. (1998) argued that food self-provisioning, interpreted as backward subsistence farming, was a common strategy to deal with market failures during the communist period. This strategy was very useful in the turbulent 1990s in Russia when economic and political transformation was accompanied by increasing unemployment, delays of wages being paid, and the collapse of agriculture. Interestingly, unconsumed food was sold only very rarely (Rose and Tikhomirov 1993), especially if home gardens were compared to family farms (Kovách 1994). Rose and Tikhomirov (1993) interpreted the situation as the demodernization and dedifferentiation of Russian society. The "Eastern urban peasantry vs. Western hobby" interpretation was strongly opposed by Jehlička and colleagues (2013), who questioned Alber and Kohler's assumptions (2008) and stressed the lifestyle aspects in postcommunist countries.

A strong counterargument against the simplified economic interpretation that "poor people produce more food because they lack income for buying the food in shops" is that the lowest social groups with the lowest incomes usually do not participate in food self-provisioning to the same extent as middle or higher income groups. This is a common phenomenon, apparent in Russia (Clarke et al. 2000; tho Seeth et al. 1998), the Czech Republic (Jehlička et al. 2013), and rural Canada (Teitelbaum and Beckley 2006). For example, only 19 percent of respondents of the lowest income group in rural areas of Canada grow vegetables, while the share is between 34 and 47 percent in the higher income groups (Teitelbaum and Beckley 2006).

Similar results occur in the Czech Republic. The rate of food selfprovisioning among the respondents who reported a "good" living standard was 48 percent, while this was only 33 percent among those who perceived their living standard as "poor" (Smith and Jehlička 2013). When controlled for other sociodemographic factors, respondents with an income in the second highest quartile participated more often in food self-provisioning than those in the lowest quartile (Jehlička et al. 2013). The most often offered interpretation is that the poorest social groups lack access to land necessary for gardening and knowledge of gardening practices. Interestingly, the results from Poland do not fully support this interpretation. The lowest income group includes 57 percent of food self-provisioners while the highest income group has only 49 percent. However, even in this case, respondents with the lowest income are not the most frequent producers. This position is occupied by the second lowest income 
group (from five groups) with 61 percent of food self-provisioners among them (Smith and Jehlička 2013).

In Ohio, Schupp and Sharp (2012) observe that although households that produce some food have higher incomes than others, this effect disappears when the other sociodemographic and geographic variables are controlled for. The authors also report the positive effect of recent economic hardship (financial problems leading to food selfprovisioning) in their survey in Ohio. This finding is in line with the argument concerning the potentially fluid character of gardens, an economically utilitarian interpretation offered by Niñez (1984): Food production gardens change to lawns and hobby and flower gardens when a family has sufficient income, but the lawns can easily be turned into productive gardens in times of crisis.

Though most of the literature is critical of the simplistic economic motivation, it is to some extent relevant for the Czech Republic and Poland, as suggested by the research. Financial motives (savings) were also mentioned relatively frequently by the respondents (Smith and Jehlička 2013).

\section{The Effect of Other Sociodemographic Characteristics}

In this section we review sociodemographic characteristics that are usually the object of research (sex, age, household type, employment, and education) but were not listed in the previous sections (place of living, type of housing, or income). We acknowledge that food selfprovisioning can often be collective work done by many household members. The nature of this activity can also be reflected in the way questions are phrased in questionnaires (e.g., the question "Does any member of your household grow food?"). Therefore, the explanatory power of the individual sociodemographic variables or values may be questionable. However, the review shows that there are several studies that have asked about the activities of household members but analyzed the characteristics individually (e.g., Brown et al. 1998; Jehlička and Daněk forthcoming; Rose and Tikhomirov 1993). Furthermore, whereas the age of the partners is often similar and there is a relatively high level of educational homogamy with roughly 50 percent of couples having the same level of education in the United States and Europe (Katrňák, Kriedl, and Fónadová 2006; Schwartz and Mare 2005), being male or female might account for some differences in gardening behavior. Rose and Tikhomirov (1993) included sex, age, and education in their international comparison of food self-provisioning. Brown et al. (1998) analyzed the effect of sex, age, ethnicity, education, and 
employment on subsistence activities (including gardening) and found some effects based on sex, age, and ethnicity. In their forthcoming article, Jehlička and Daněk reveal that age and individual values influenced the amount of own-produced food shared in the Czech Republic. Thus, we decided to include the individual characteristics into the literature review and data analysis, and we use caution in interpreting the results.

Respondents' sex is sometimes reported as an important factor. Home gardens at Austrian farms are usually managed by women (Vogl and Vogl-Lukasser 2003). Gray et al. (2014) also report higher activity of women in a San Jose, California, case study. Reyes-García et al. (2010) point to different management techniques and the different handling of garden products by women and men in Spanish rural areas. In another Spanish case study in the city of Terassa, men were the dominant users of the allotment gardens (Domene and Saurí 2007). Research done in the Czech Republic and Poland (Jehlička et al. 2013; Smith and Jehlička 2013) finds no sex differences in food selfprovisioning. Rose and Tikhomirov (1993) also did not find any sex differences in their research in central and eastern Europe in the early 1990s.

No effects of age were found in Poland, where the range of food selfprovisioning is between 53 and 59 percent in all age groups (Smith and Jehlička 2013). The analysis of Czech respondents, however, reveals the positive effect of age, with a higher rate of food growing with older age (Jehlička et al. 2013). Rose and Tikhomirov (1993) also found no effect of age.

The share of food self-provisioners increases with an increase in the number of household members in Poland (32 percent of single households but 63 percent of households with more than four members) (Smith and Jehlička 2013). Rose and Tikhomirov (1993) also found an increasing share of food self-provisioning with an increasing size of a household in all countries surveyed (Bulgaria, Poland, former Czechoslovakia, and Russia).

With regard to employment patterns in Poland, food selfprovisioning is an activity of 49 percent of the unemployed, 52 percent of students, 54 percent of pensioners, and 61 percent of housewives. The share among employed respondents ranges between 46 and 58 percent, according to the type of employment (Smith and Jehlička 2013). The research in the Czech Republic found similar results: 56 percent of pensioners, 43 percent of the unemployed and self-employed, 39 percent of housewives, and 35 percent of qualified workers are participating in food self-provisioning (Jehlička et al. 2013). There is no effect of the employment level on food self-provisioning in rural Canada; all 
categories range between 37 and 47 percent of participation (Teitelbaum and Beckley 2006). Employment characteristics (having a regular job, number of employed members of the household, or being retired) had no effect on food self-provisioning in Bulgaria, Poland, and the former Czechoslovakia (Rose and Tikhomirov 1993).

There is no significant effect of education either in the Czech Republic or in Poland. In both countries the share of food selfprovisioners with various education levels oscillates around the national averages of 43 and 54 percent, respectively (Smith and Jehlička 2013). None of the four countries surveyed by Rose and Tikhomirov (1993) reported any effect of education either.

\section{Motivation for Food Self-provisioning}

Cultural and lifestyle motivations of food self-provisioning are important. Growing food as a tradition is often mentioned by Australian gardeners (Larder et al. 2014). Tradition, identity, and familiarity with gardening when growing up were found to be important factors for some gardeners in the Canadian study of Kortright and Wakefield (2011). Cultural aspects are also apparent in the Mississippi Delta case study, in which Brown et al. (1998) label food self-provisioning as "subsistence," which has to do not only with economic needs but also with lifestyle and culture. "Subsistence" can be opposed to the term "informal economy," perceived as more utilitarian and financially motivated. Teitelbaum and Beckley (2006) offer a similar interpretation in the case of rural Canada. The authors conclude that food selfprovisioning is a culturally embedded activity important for many rural households. Recreation and contact with rural traditions are important aspects of food self-provisioning as shown in a Spanish case study on allotment gardens in the city of Terassa (Domene and Saurí 2007).

Traditions and the perception of gardening as a hobby are also very important in central and eastern Europe, as opposed to the interpretation of food self-provisioning as driven mainly by economic needs (see the subsection on "Economic Interpretation"). Clarke et al. (2000) argue that food self-provisioning can also be seen as leisure activity, especially for the better-off in Russia. According to a Czech survey, the second most common motivation for food self-provisioning in 2005 and 2010 was as a "hobby," and this was also one of the most important motivations for Polish food producers (Smith and Jehlička 2013). The primary motivation of both Czech and Polish gardeners was fresh and healthy food (Smith and Jehlička 2013). Other studies as well found 
the quality of the food to be very important (Domene and Saurí 2007; Gray et al. 2014).

While the perception of gardening as a traditional activity seems to be very similar in different places around the world, there are big differences in the contextualization of food self-provisioning as being environmentally friendly. This can be seen as an example of reflexive behavior, in contrast to tradition, convenience, or economic necessity. In their Ohio case study, Schupp and Sharp (2012) found a link between general proenvironmental behavior (including recycling or using one's own bag when shopping) and involvement in food self-provisioning. Additionally, the food self-provisioners are more often engaged in local food systems (farmers' markets, pick-your-own crops, local food). Larder et al. (2014) report sustainability and environmental concerns as one of the most important topics mentioned by the Australian gardeners in their qualitative study. Similarly, Kortright and Wakefield (2011) find environmental motivation in the case of Toronto gardeners.

The interpretation of the Czech case is different. Jehlička and Smith (2011:370) understand food self-provisioning as a component of "selfidentity and 'authenticity' that, incidentally, reduce the self-provisioners' environmental impact." They include food self-provisioning in their concept of "quiet sustainability," which is beneficial for the environment and society but not consciously linked to the sustainability or environmental concern of the practitioner (Smith and Jehlička 2013:155).

Due to the specifics of our data, we have had to use some indirect indicators. We are convinced that food consumption habits can be used as a relevant proxy to discuss the motivation of the food self-provisioners, as the literature on food choices suggests. Self-provisioned food is local, seasonal, and often organic. Market research shows that organic, local and seasonal food is, in general, viewed as environmentally friendly (Lockie et al. 2002; Tobler, Visschers, and Siegrist 2011) and that environmental concern is an important driver in choosing organic, local, and seasonal food (Boccalletti 2008; Lockie et al. 2002; Siegrist, Visschers, and Hartmann 2015). Therefore, the purchase of food is at least for some social groups a reflexive practice, in contrast to only convenience behavior (Fonte 2013; Hjelmar 2011). The reflexive nature of food purchasing suggests that food consumption can help to interpret potential proenvironmental motivations also in the case of food self-provisioning.

\section{Our Research Questions}

The results summarized in the literature review portray food selfprovisioning as a widespread activity, influenced mostly by access to 
gardens and only weakly by sociodemographic characteristics. Economic motivation is to some extent important; however, tradition, leisure, and cultural motives seem to be crucial. Given the reported level of food self-provisioning in various European states (especially those with different economic and political histories) and building on the results of previous quantitative studies, we defined the following research questions:

1. What is the level of food self-provisioning in selected European regions and how do they differ from each other?

2. Which sociodemographic and geographical characteristics influence participation in food self-provisioning?

3. How can we interpret the motivations for food self-provisioning using sociodemographic characteristics and food consumption preferences as proxy indicators?

\section{Methods}

We collected the data during the fieldwork of the European Union Seventh Framework Program research project called GILDED, which focused on the socioeconomic, cultural, and political context of households' energy use and possibilities of lowering their carbon footprint. Since the carbon footprint of food constitutes a significant part of the overall carbon footprint of households (Schächtele and Hertle 2007; Vávra and Lapka 2013), the information about food self-provisioning is important as it can contribute to the lowering of carbon emissions.

\section{Research Areas}

This study included regions from five EU countries: Aberdeenshire in Scotland, the Assen region in the Netherlands, the Potsdam region in Germany, South Bohemia in the Czech Republic, and Hajdú-Bihar County in Hungary. The five countries represent a crosscut through the EU and are characterized by different socioeconomic circumstances, historical experience, and natural conditions. In each country we chose a region with an urban center and its rural surroundings. The regions represent relatively distant areas from the countries' centers with a lower population density and (with one exception) gross domestic product (GDP) than the countries' averages. All five areas are "[i]ntermediate rural regions, close to a city" according to the EU territorial categorization (Gotts and Kovách 2010:6). The project aimed to focus 
on such "common" regions, so as not to be biased by the metropolitan areas but to still include the middle-sized cities.

The Scottish site consists of the city Aberdeen (population approximately 200,000) and the rural areas of Aberdeenshire (population 50,000 including small towns) in northeast Scotland, an area with a very low population density (40 inhabitants per square kilometer for all of Aberdeenshire) and with an oil industry in Aberdeen city. The gross domestic product (purchasing power standard) of the United Kingdom was 26,300 Euros per year per person in 2010, while Scotland's GDP per person was 24,200 Euros and northeastern Scotland's was 39,000 Euros due to the oil industry.

The Dutch research areas are the city of Assen (population 67,000) and the rural parts of Assen municipality, both situated in the province of Drenthe (overall population 490,000) in the northern part of the Netherlands. The whole province of Drenthe shows a relatively high population density (182 inhabitants per square kilometer excluding Assen), compared to the other study regions, although lower than the rest of the Netherlands. The GDP of the Netherlands was 31,700 Euros per year per person while Drenthe's GDP was 23,600 Euros per year per person.

The city of Potsdam (population 160,000) and the rest of the Potsdam-Mittelmark District (population 44,000 including small towns) represent the study sites in Germany. Population density of the whole area is 80 inhabitants per square kilometer. This area is found in Bundesland Brandenburg, in the former East Germany, in the northeast part of the country. The GDP of Germany was 29,200 Euros per year per person while the GDP of Brandenburg was 20,900 Euros per year per person.

In the Czech Republic the research area consists of the city of České Budějovice (population 94,000) and rural municipalities from the former administrative districts of České Budějovice and Český Krumlov (population excluding the city of České Budějovice is 158,000). Our research area belongs to the South Bohemian Region, a higher administrative unit with a relatively low population density (63 inhabitants per square kilometer) and with a rural character compared to the rest of the Czech Republic. The GDP of the Czech Republic was 19,700 Euros per year per person, while the GDP of the Southwest Region (a larger unit including South Bohemia) was 17,100 Euros per year per person.

The Hungarian study site includes the city of Debrecen (population 207,000) and the surrounding rural area in Hajdú-Bihar County (population 340,000 including other towns in the county; overall population density 88 inhabitants per square kilometer) situated in northeast Hungary. The area is characterized by agriculture. The Hungarian GDP was 
16,100 Euros per year per person; the area of Northern Great Plain (a larger unit including Hajdú-Bihar County) had a GDP of 10,300 Euros per year per person. For detailed geographical and socioeconomic information about all of the study sites see Gotts and Kovách (2010).

While Scotland and the Netherlands represent the traditional western European countries with long-term experience with the market economy, Brandenburg used to be part of communist East Germany, which reunited with West Germany in 1990 and experienced a high level of migration from the former West Germany after reunification. The Czech Republic (part of the former Czechoslovakia) and Hungary are central European postcommunist countries representing central and eastern Europe. The overall level of economic wealth (as indicated by GDP) still reflects the history of the countries. Although we are aware that we use regional samples that are not nationally representative, we use the names of the countries (e.g., the Netherlands, Dutch) instead of the regions.

The five selected areas (Figure 1) belong to various environmental zones according to Metzger et al. (2005). ${ }^{3}$ Different natural conditions may, to some extent, prefigure the kind and volume of agricultural production although gardeners are able to influence many variables (by watering, manuring, or using greenhouses). Aberdeenshire and Assen area (Scotland and the Netherlands) are situated in the Atlantic North Zone characterized by higher humidity and less interseasonal variation than the other zones. The Atlantic North Zone, as a whole, is generally less favorable to agriculture. The Continental Zone includes the regions of Potsdam area and South Bohemia (Germany, the Czech Republic) and is characterized by the variation of the typical four seasons and great interseasonal variability and provides quite favorable conditions for crops. Debrecen area in Hungary belongs to the Pannonian Zone, defined as a continental climate with typical cold winters and warmer and drier summers. Generally, this region is favorable for growing warm-season crops.

\section{Survey and Data Processing}

The survey was carried out in the spring of 2010. We combined quota, cluster, and random sampling to achieve a representative sample according to the given quotas of age and sex. However, the sociodemographic structure is influenced by the nonrepresentative distribution of

\footnotetext{
${ }^{3}$ Due to the climate change in progress, some environmental conditions within the zones are now observed to be undergoing change, especially the distribution of precipitation, length of the vegetation season, or frequency of extreme weather and climate events (Trnka et al. 2011), but the general characteristics are applicable.
} 


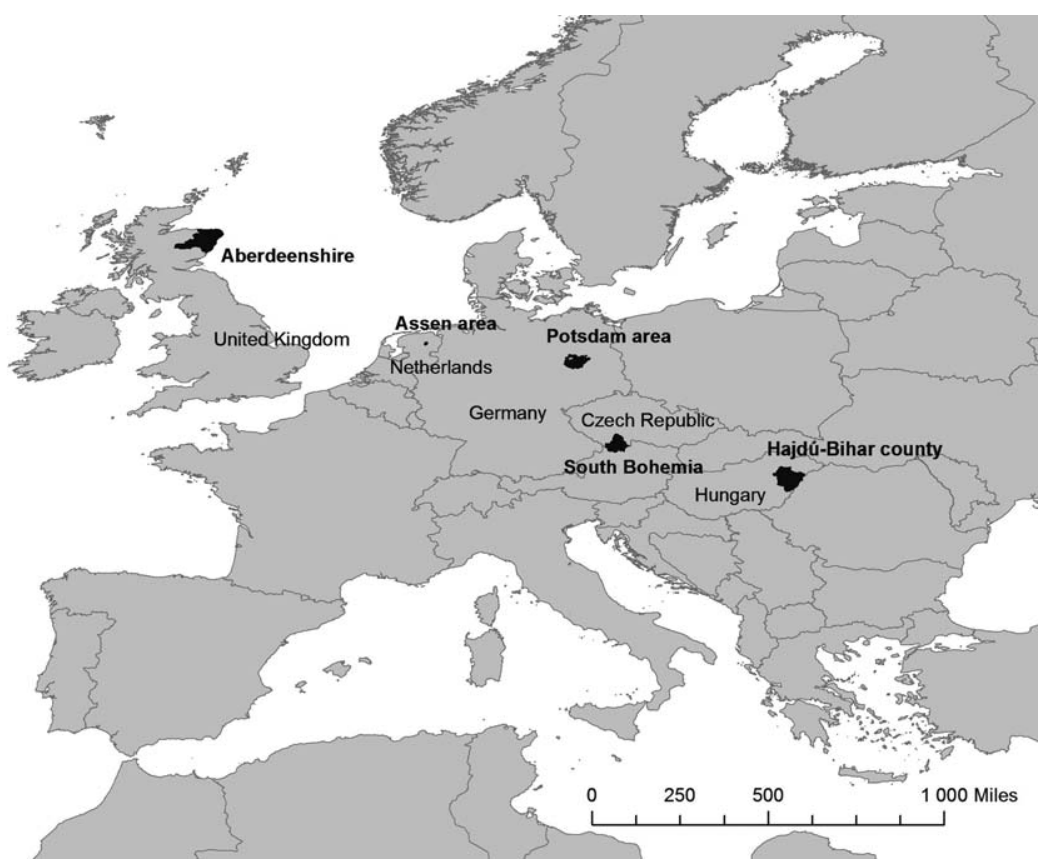

Figure 1. Food self-provisioning in Europe: the study regions.

Source: Our processing in ArcGIS 10.4 based on data source GADM spatial database (http://www.gadm.org/home). Note: Coordinate system GCS ETRS 1989.

place of living (half urban, half rural) given by the focus of the original GILDED research project on an urban-rural comparison (using a threshold of 2,000 or 3,000 inhabitants in a municipality as defining "urban" with some local exceptions) ${ }^{4}$ Considering the equal urbanrural ratio, our sample is representative for the study areas (Table 1) although the scaling up of the results to the country level can be done only very cautiously (e.g., due to the higher ratio of owners and houses in our samples). The questionnaires were distributed and collected door to door, usually by members of the research team and students. There were two exceptions. In the Czech Republic a market research company did the fieldwork while in Scotland the door-to-door method

\footnotetext{
${ }^{4}$ The definition of urban and rural areas follows the official governmental typology in Scotland with the rural-urban threshold of 3,000 inhabitants in a municipality. In the Netherlands, rural areas in the sample consist of small villages and one small town with over 2,000 inhabitants. Similarly, in the Czech Republic and Hungary a few remote local towns with over 2,000 inhabitants are included in the rural sample. The German rural sample does not include any municipalities over this population threshold.
} 


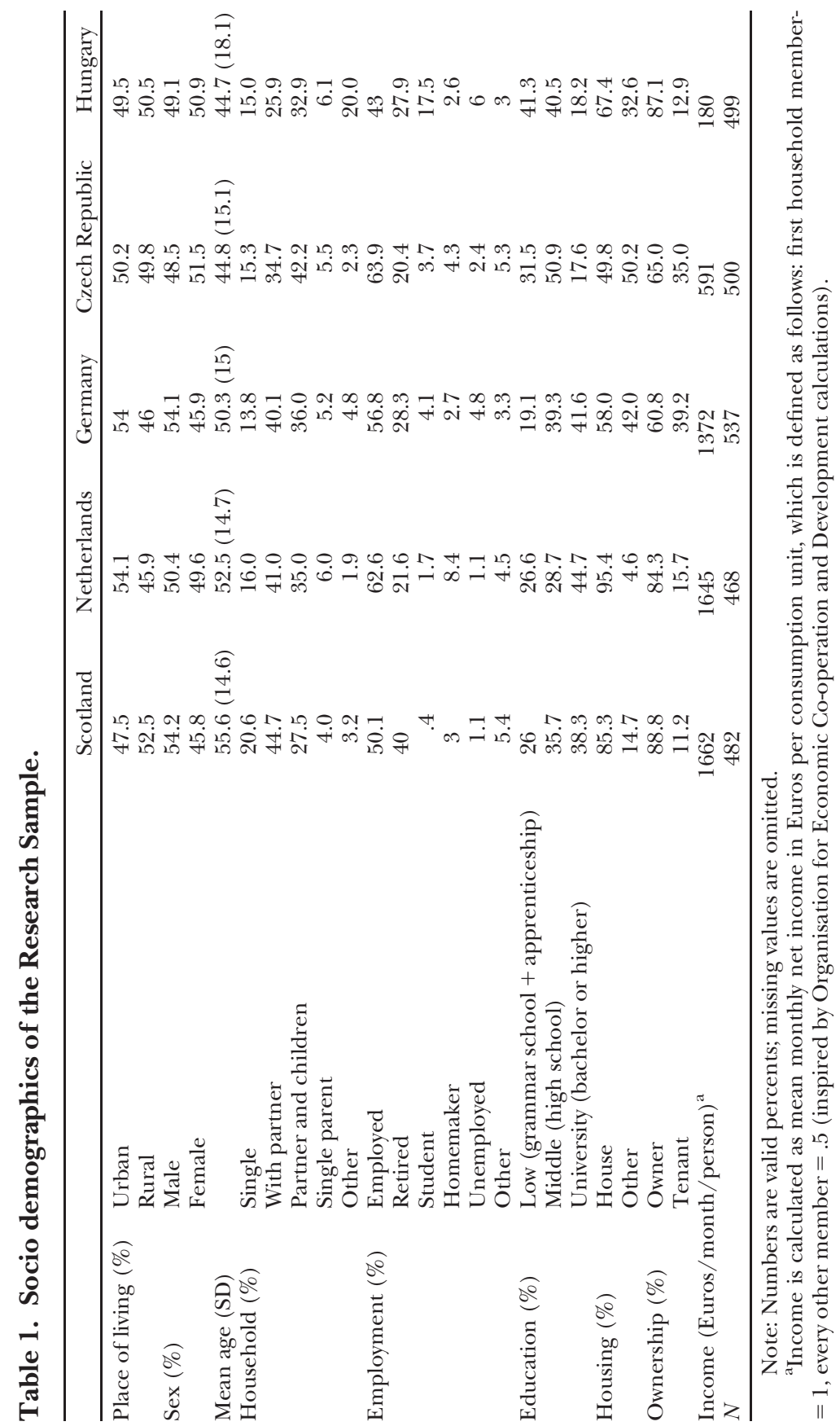


was combined with a postal method. Together we collected 2,486 completed questionnaires with an overall response rate of 32 percent. The quantitative nature of the survey, necessary for the purpose of the original project, unfortunately does not allow us to fully interpret some of the detailed findings (see below).

The major question respondents were asked was "Do you produce any food products on your own?" 5 The question was asked in the context of a whole household, thus it provides information on whether any member of the household participates in food self-provisioning. This might make the interpretation of the effect of sociodemographic variables (especially sex, age, or education) more difficult; however, this approach has already been successfully applied in previous research (see the review in the "Effect of Other Sociodemographic Characteristics" subsection). In our analysis, we enter individual characteristics along with the household independent variables (thereby controlling for the influence of individual respondents' characteristics on the dependent variable), but we interpret them cautiously and acknowledge the consequent limitations of the data in the results and discussion section.

The answers to the question on food self-provisioning were coded as $0=$ no; $1=$ yes. We used this question as a dependent variable in the logistic regression. Other statistical methods included Pearson's correlation and chi-squared tests for the analysis of the categorical data. We performed analyses in SPSS Statistics 19. We dichotomized most of the variables used in the logistic regression as independent (place of living, sex, type and ownership of property) or categorized them (country, age groups, education, household type, employment status, income split into five quintiles); see Table 1 and Table 3. Regarding the type of housing, the house category includes various types of single family homes (regardless of whether a house was detached, semidetached, or terraced), which we understand as a proxy indicator for having a garden. ${ }^{6}$ We used data for food consumption as scale variables, expressing how often respondents consumed regional, seasonal, or organic food (ranging from $1=$ never to 7 =always). According to the literature

\footnotetext{
${ }^{5}$ This provides information about how widespread food self-provisioning is among the samples of respondents; however, it does not reveal how much food is produced. This can differ significantly even in the same place, as the research on Czech allotment gardeners illustrates (Sovová 2015).

${ }^{6}$ However, as the results show, food is produced also in other types of gardens than the family house gardens (e.g., allotment or community gardens, weekend houses). Additionally, some two-to-three-story houses or multistory apartment buildings can also be accompanied by gardens.
} 
Table 2. Percentage of Food Self-provisioning.

\begin{tabular}{|c|c|c|c|c|c|c|c|c|c|c|}
\hline & \multicolumn{2}{|c|}{ Scotland } & \multicolumn{2}{|c|}{ Netherlands } & \multicolumn{2}{|c|}{ Germany } & \multicolumn{2}{|c|}{$\begin{array}{c}\text { Czech } \\
\text { Republic }\end{array}$} & \multicolumn{2}{|c|}{ Hungary } \\
\hline & Urban & Rural & Urban & Rural & Urban & Rural & Urban & Rural & Urban & Rural \\
\hline $\begin{array}{l}\text { Share of } \\
\operatorname{FSP}^{\mathrm{a}}(\%)\end{array}$ & 30.6 & 52.2 & 13.4 & 27.0 & 32.1 & 57.5 & 34.7 & 56.6 & 49.4 & 44.8 \\
\hline $\begin{array}{l}\text { Chi-squared } \\
N\end{array}$ & \multicolumn{2}{|c|}{$\begin{array}{c}23.05^{* * * *} \\
482\end{array}$} & \multicolumn{2}{|c|}{$\begin{array}{c}13.49 * * * \\
468\end{array}$} & \multicolumn{2}{|c|}{$35.03 * * *$} & \multicolumn{2}{|c|}{$24.31 * * *$} & \multicolumn{2}{|c|}{$\begin{array}{r}1.037 \\
499\end{array}$} \\
\hline
\end{tabular}

Note: All results of chi-squared test are on the level of 1 degree of freedom. ${ }^{\mathrm{a}} \mathrm{FSP}=$ food self-provisioning. $* * * p \leq .001$.

review, food consumption preferences can be used as a proxy indicator for proenvironmental motivation. Empirical research shows that the perception and definition of "local" food is quite wide (Ballute and Berger 2014) and varies by context and from country to country (Hiroki, Garnevska, and McLaren 2016). The term "regional" used in our questionnaire can be even broader, covering the range of products from a hometown to the region and even to the whole country in the case of smaller countries.

\section{Results and Discussion}

First, we present an overall international comparison of food selfprovisioning, followed by a brief report on individual countries including the effects of geographic, economic, and other sociodemographic and food consumption factors. We then discuss the results in the context of previous research with an emphasis on the effect of explanatory variables and their role in different countries.

The overall share of people who participate in food self-provisioning is relatively high in four of the countries or regions but not in the Netherlands (see Table 2). One of the reasons for the relatively low level of food self-provisioning in the Netherlands may be the high population density and the urban character even of the rural regions. Apart from the Dutch case, the share of food self-provisioners ranges from 31 to 49 percent in urban areas and from 45 to 58 percent in rural areas. The Hungarian case shows more food self-provisioners in the cities and towns than in villages but the difference is not statistically significant. The big difference between Scotland and the Netherlands (two countries with similar environmental conditions) and smaller differences between Scotland and the other countries (with better environmental conditions) suggest that the natural circumstances are not that important for food self-provisioning in the case of our selected regions. 
To scale the regional results up to a country level is possible but we have to keep in mind that our regions are specific and the owners of property and houses are overrepresented in the samples, especially in Scotland, the Netherlands, and Hungary. If the data are weighted according to the real share of urban and rural population in the countries (ranging from 71 percent of the population in Hungary being urban to 90 percent in the Netherlands [United Nations 2014]), the share of food self-provisioning is as follows: Hungary 48 percent, the Czech Republic 40 percent, Germany 38 percent, Scotland and United Kingdom 34 percent, and the Netherlands 14 percent. The limitation of the weighting process is probably most apparent in the United Kingdom due to the very rural character of the study region, which leads to the overvaluation of food self-provision at the country level.

Table 3 includes the results of logistic regressions with six models, one for all of the countries combined and one for each separate country. Missing values were deleted listwise, thus not all of the respondents entered the regression. The overall explanatory power of the models is sufficient, being 27 percent for the international comparison and ranging from 22 percent of explained variability in the Dutch sample to 48 percent in the Hungarian case (value of Nagelkerke $R^{2}$ multiplied by 100; see Table 3). ${ }^{7}$ When all countries are analyzed together, nationality is a significant predictor, more important than any other independent variable.

Living in one's own property, living in a rural area, having a partner, or being retired, a homemaker, or unemployed all significantly increase the probability of self-provisioning of food (the effect of rural area and homemaker-unemployed factors is only marginally significant). Similarly, consuming organic, seasonal, and local food is also linked with a higher occurrence of food self-provisioning. A higher income, however, is connected to a lower share of food growing. As the outcomes of the models for individual countries suggest, some of these significant results of overall regression with an international sample are caused only by the specifics of some countries.

In Scotland, food growing is more apparent among respondents living in houses, those living in rural areas, those living with a partner, and those with higher education. Respondents fitting into the third to fifth income quintiles as well as the age group of 60 or more years tend to grow food less often (than the low income group or respondents

\footnotetext{
${ }^{7}$ We calculated the models without the independent variable of sex as well. These regressions did not reveal any important change in the overall meaning and explanatory power of the variables in the regressions.
} 
Food Self-provisioning in Europe — Vávra et al. 21

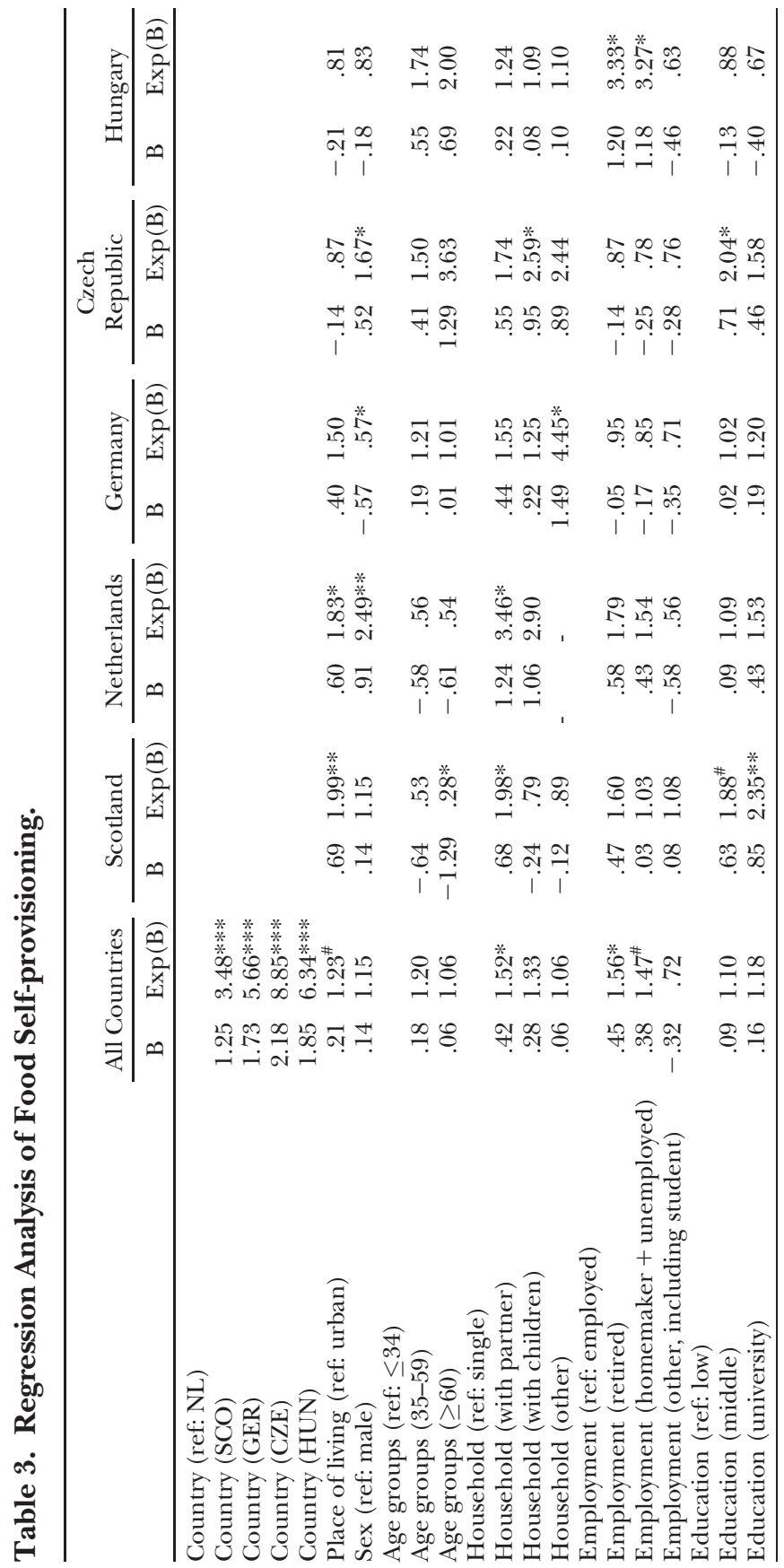




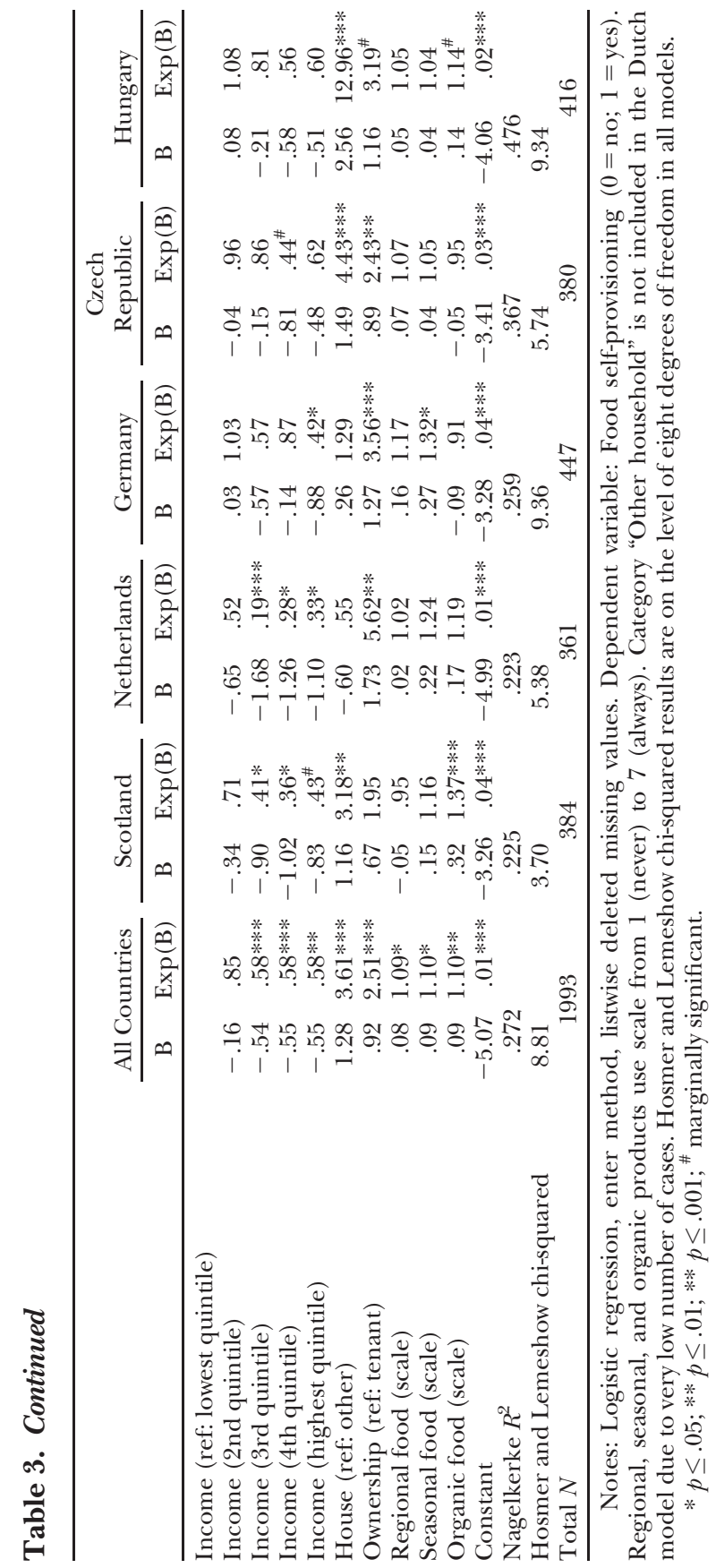


under 35 years of age used as reference). Consumption of organic food also increases the probability of food self-provisioning.

Among the Dutch respondents, owners of their own housing, people in rural areas, females, and those who live with a partner are more active in food production. Similarly, as in Scotland, the third to fifth income quintiles show lower probability of producing food.

In Germany, respondents living in their own properties, males, and those who often consume seasonal food participate more in food selfprovisioning. Frequent food production of the "other" household group is caused by some local specifics (young rural workers and students producing the food). Only the highest income group significantly differs from the lowest income group by showing lower food production activity.

Living in a house or one's own property, having middle-level education, living with children, and being female are significant predictors of higher food production activity in the Czech Republic. There is no significant effect of income or any other variable.

Living in a house is a significant predictor of food self-provisioning in Hungary (very strong), as well as being retired, unemployed, or a homemaker. Ownership of property has a marginal significance linked with higher food self-provisioning activity. Similarly, consumption of organic food is linked with higher food production activity of marginal significance.

Scotland shows the highest number of statistically significant predictors of food self-provisioning of all the countries, which suggests that the activity is more socially differentiated than in the other countries. Contrary to this, only a few predictors were significant in the case of Hungary, suggesting low social differentiation.

The relatively high share of food self-provisioning in most of our research areas is in accordance with the results of previous research in the United States, Canada, and various European countries. This finding supports the idea that food growing is also generally widespread among the populations of the Global North. The difference between our results and research done by Alber and Kohler (2008) may be caused by the methods and possible underestimation of food selfprovisioning by their data source and specifics of our research regions.

Living in a house (understood as a proxy for having a garden) or ownership of the property are the most important predictors for food self-provisioning. At least one of them is statistically significant in each country. Additionally, these two factors are positively correlated ( $p=.000$ in all countries). The share of food self-provisioners among those respondents who live in houses is as follows: the Czech Republic 
71 percent, Hungary 65 percent, Germany 57 percent, Scotland 46 percent, and the Netherlands 20 percent. A house as a type of housing is positively correlated with living in rural areas in all countries $(p=.000)$, except in Hungary $(p=.878)$ in which the share of houses is the same in rural as well as in urban regions. When controlled for ownership and type of housing, rural residence is important only in Scotland and the Netherlands, where rural residents participate more in food selfprovisioning.

This divides the countries into two groups from an "access to land" point of view. Food self-provisioning as a rural activity (Scotland and the Netherlands) and food self-provisioning as an activity of anyone who has a garden regardless of the place of living (Germany, the Czech Republic, and Hungary). The results in the central European group seem to be more similar to the results found in central and eastern Europe by Rose and Tikhomirov (1993) or in Ohio by Schupp and Sharp (2012).

For the analysis of the effect of income, we used the lowest quintile as a reference category. Other income groups in all countries, except the second lowest quintile in Germany and Hungary, show a lower probability by an insignificant trend than the lowest income category. However, the results are more often significant in Scotland and the Netherlands but not in the other countries (except the effect of the highest income group in Germany). As financial motivation is widely discussed in the literature, we also tested the effect of income groups on food self-provisioning without controlling for other variables. Significant findings appear only in the Czech Republic $\left(\chi^{2}=16.96 ; p=.002\right)$ where the lowest income group shows a higher probability of food selfprovisioning and the second highest income groups a lower probability. A similar, nonsignificant trend can also be found in the Netherlands.

The lowest income groups in all countries tend to live less often in houses while people in houses significantly more often grow their own food. Despite this, the lowest income groups tend to grow their food more often than higher-income respondents. This supports the economic motivation of food self-provisioning among them. It should be said that "another" type of housing also includes apartments in two-tothree-story houses (for example, relatively often with a garden in the United Kingdom, the Netherlands, or the Czech Republic) or a multistory apartment building, whose owners might have access to allotment gardens or weekend houses (cabins) with gardens. Based on this, we argue that even the lowest income groups do not lack access to land as often as is the case of Canada or Russia (Clarke et al. 2000; Teitelbaum and Beckley 2006; tho Seeth et al. 1998). 
The effect of income in our case studies tends to be the opposite to what Jehlička et al. (2013) found in the Czech Republic and Schupp and Sharp (2012) in the United States. However, as we do not know the direct motivation, we have to be aware of generalizations and a strictly economic interpretation. For example, Brown and colleagues (1998) interpreted food self-provisioning as a cultural tradition of lower income groups rather than a utilitarian activity caused by low income per se.

Being a man or a woman is important in Germany (men being more active in food self-provisioning), and in the Dutch and Czech samples (women growing food more often), although the effect of sex is a bit complicated. Even if one person is the main gardener, the other family member(s) also participate in food production (Gray et al. 2014; ReyesGarcía et al. 2010). Therefore, it is hard to interpret the results of our study with regard to the differences in sex because we analyzed the whole household self-provision rate regardless of whether the main respondent was a man or a woman.

The effect of age on food self-provisioning is relatively weak according to our research and similarly as in the case of sex, more family members may participate in food production. When other variables are controlled, age has no effect on food self-provisioning in any of the countries except Scotland ( $\geq 60$ being less active in food self-provisioning). If other variables are not controlled for, however, there is a significant relationship between age and food self-provisioning in the Czech Republic $\left(\chi^{2}=19.06 ; p=.000\right)$ and in Hungary $\left(\chi^{2}=48.16 ; p=.000\right)$, accompanied by a similarly marginally significant trend in Germany $\left(\chi^{2}=5.90 ; p=.052\right)$. In all three countries, people younger than 35 years old grow food less often than those in the age category $\geq 60$. As older age is often linked with being retired, having a lower income, or living in a rural area and house, these factors explain the variability in the regression instead of the age. The outcomes of previous research also offer various relationships between age and food self-provisioning. Domene and Saurí (2007) present a case study of Spanish allotment gardens used mostly by older men and Jehlička et al. (2013) also found that older people grow food more often than younger ones in the Czech Republic, while age was not important in Poland (Smith and Jehlička 2013).

Food self-provisioning is a family activity more common among households of couples (Scotland, the Netherlands) or couples with children (the Czech Republic). Additionally, living with a partner or having children increases insignificantly the probability of food growing in Germany. Living with a partner also has an insignificant positive effect 
in the Czech Republic. Having children may increase some healthrelated motivations for food self-provisioning (e.g., fresh and healthy food, being outdoors). Kortright and Wakefield (2011:44-45) used the term "teaching garden" with the main motivation of respondents being to teach the processes of food growing to the children in the authors' research.

Being retired, a homemaker, or unemployed significantly increases food self-provisioning activity in Hungary. Retired people also tend to be more active in food self-provisioning in Scotland and the Netherlands but the difference is not statistically significant.

The effect of education varies among the countries. We can see no effect in Germany, Hungary, or the Netherlands (only the nonsignificant positive effect of highest education). But both middle and higher education levels significantly increase the probability of food growing in Scotland. A middle education level has the same effect in the Czech Republic. The influence of education may also be limited by the fact that food self-provisioning tends to be a household activity but we asked for the education of the individual respondent.

Previous research found little or no effect of household type, employment status, or education level on food self-provisioning (e.g., Jehlička et al. 2013; Rose and Tikhomirov 1993; Teitelbaum and Beckley 2006).

The explanatory power of food consumption habits is rather low, with only a significantly higher consumption of organic food being linked with higher food self-provisioning activity in Scotland and being of marginal significance in Hungary. More frequent consumption of seasonal food is significantly linked with food growing in Germany and by a nonsignificant trend in the Netherlands. Our results are in line with the previous studies that found some link between proenvironmental behavior or environmental concern and food self-provisioning (Larder et al. 2014; Kortright and Wakefield 2011; Schupp and Sharp 2012), but it would be too presumptuous to label food self-provisioning as reflexive behavior based on our data. It should be said that the consumption of organic, regional, and seasonal food could also be a function of food self-provisioning (consuming one's own food). However, the fact that this relationship was not found in all countries suggests that respondents focused more on shopping habits when answering these questions as opposed to the consumption of self-produced food. Therefore, food consumption may help to interpret the motivation for food self-provisioning, especially in Scotland, where we can cautiously discern some level of reflexivity and proenvironmental motivation (preference for organic food, lower age group being more active in food self-provisioning, and positive effect of higher education). 
The choice of regional food was significant only for the international sample as a whole and only by an insignificant positive trend in all countries except Scotland. The lack of a significant relationship between food self-provisioning and the consumption of regional food is not in itself surprising given the specific aspects of the choices of local food. As Conner et al. (2010) and Memery et al. (2015) showed, the context of support for local farmers and community is more important than many other aspects such as proenvironmental attitudes.

\section{Conclusions}

We conclude that food self-provisioning is a relatively widespread activity in all of the regions researched except in the Dutch case study. The share of food self-provisioning is only 13 percent among Dutch urban areas and 27 percent in the rural areas. In the other countries, the share is between 31 percent in Scottish urban areas and 58 percent in German rural areas.

The effects of sociodemographic and geographic factors on food self-provisioning differ among the individual countries, except for the positive effect of living in a house or one's own property and a similar trend in the negative effect of increasing income. In Scotland, the food is grown mostly by respondents who live in rural areas or in houses, are well educated, live with a partner, tend to have a lower income, and consume more organic food. Among all of our respondents, the Scottish sample shows the highest social differentiation and may have the highest share of reflexive food self-provisioners. Scottish gardeners also produce food quite often despite the fact that the natural conditions are far from being ideal.

In the Netherlands, the important factors are living in one's own property and in a rural area, being female, having a partner, and having a lower income. We interpret the food self-provisioning in the Netherlands as a rather rare activity practiced mostly by rural families.

German food producers are mostly respondents who live in their own property, are more often males, and choose seasonal food more often. The effect of other variables is weak and only the highest income group differs significantly. In light of this finding, we can say that food self-provisioning is a widespread hobby or traditional activity.

Living in a house or one's own property, having children, being female, and having a midlevel education are key factors for food selfprovisioning in the Czech Republic. The activity can also be interpreted as a widespread traditional activity or hobby, especially of middle-class families. 
Important factors for food self-provisioning in Hungary are living in a house or one's own property and being retired, unemployed, or a homemaker. Hungarian food growers also tend to consume organic food more often. Food self-provisioning seems to be mostly a function of having a garden and time, which can be interpreted as a strong tradition or by some utilitarian motives. However, the consumption of organic food may be caused by some reflexive motives.

There is one common trait for all countries, which to some extent contradicts previous research. This is the tendency of lower income groups to participate more often in food self-provisioning. This supports the relevance of economic motivation or a subsistence interpretation of the lifestyle choice of lower income groups. Some similarities (e.g., the lower effect of income) also differentiate Germany, the Czech Republic, and Hungary from the Netherlands and Scotland, which suggests that a shared geographic condition, cultural space, and history (including the communist era) may be more important than the usual political East-West distinction.

We believe that our study contributes to the knowledge of how common a practice food self-provisioning in Europe is and what factors influence it. We also have discussed the motivation behind it using sociodemographic and other proxy data. However, our research has some limitations. One of these is the fact that some of the variables were collected at an individual level, while food self-provisioning is considered as a household activity. That is why the influence of some characteristics (e.g., sex, age, or education) should be interpreted cautiously. Other limitations of the study are its regional character and the lack of knowledge of how much food is actually produced. Therefore, we conclude that there is a need for future comparable representative national or international studies that could reveal more about the motivation for food selfprovisioning among the population of the largely urbanized and industrialized countries of the Global North. Future research should also focus on the intrahousehold dynamics of food self-provisioning (who is involved in the activity) and the examination of the real production potential of gardeners and the extent of their self-sufficiency.

\section{References}

Alber, Jens and Ulrich Kohler. 2008. "Informal Food Production in the Enlarged European Union." Social Indicators Research 89:113-27.

Ballute, Andrea K. and Paul D. Berger. 2014. "The Perceptions of and Motivations for Purchase of Organic and Local Foods." Journal of Contemporary Issues in Business Research $3(1): 1-18$.

Boccalletti, Stefano. 2008. "Environmentally Responsible Food Choice." OECD Journal: General Papers 2008(2):117-52. 
Brown, Ralph B., Xia Xu, and John F. Toth Jr. 1998. "Lifestyle Options and Economic Strategies: Subsistence Activities in the Mississippi Delta." Rural Sociology 63(4): 599-623.

Calvet-Mir, Laura, Maria Calvet-Mir, Laura Vaqué-Nuñez, and Victoria Reyes-García. 2011. "Landraces in situ Conservation: A Case Study in High-Mountain Home Gardens in Vall Fosca, Catalan Pyrenees, Iberian Peninsula." Economic Botany 65(2):146-57.

Cameron, Ross W. F., Tijana Blanuša, Jane E. Taylor, Andrew Salisbury, Andrew J. Halstead, Béatrice Henricot, and Ken Thompson. 2012. "The Domestic Garden-Its Contribution to Urban Green Infrastructure." Urban Forestry and Urban Greening 11: 129-37.

Clarke, Simon, Lena Varshavskaya, Sergei Alasheev, and Marina Karelina. 2000. "The Myth of the Urban Peasant." Work, Employment and Society 14(3):481-99.

Conner, David, Kathryn Colasanti, R. Brent Ross, and Susan B. Smalley. 2010. "Locally Grown Foods and Farmers Markets: Consumer Attitudes and Behaviors." Sustainability 2:742-56.

Dewaelheyns, Valerie, Annemie Elsen, Hilde Vandendriessche, and Hubert Gulinck. 2013. "Garden Management and Soil Fertility in Flemish Domestic Gardens." Landscape and Urban Planning 116:25-35.

Domene, Elena and David Saurí. 2007. "Urbanization and Class-Produced Natures: Vegetable Gardens in the Barcelona Metropolitan Region." Geoforum 38:287-98.

Duží, Barbora, Attila Tóth, Mária Bihuňová, and Robert Stojanov. 2014. "Challenges of Urban Agriculture: Highlights on the Czech and Slovak Republic Specifics." Pp. 82107 in Current Challenges of Central Europe: Society and Environment, edited by J. Vávra, M. Lapka, and E. Cudlínová. Prague, Czech Republic: Faculty of Arts, Charles University.

Fonte, Maria. 2013. "Food Consumption as Social Practice: Solidarity Purchasing Groups in Rome, Italy." Journal of Rural Studies 32:230-39.

Galhena, Dilrukshi Hashini, Russell Freed, and Karim M. Maredia. 2013. "Home Gardens: A Promising Approach to Enhance Household Food Security and Wellbeing." Agriculture and Food Security 2(8):1-13.

Gibas, Petr, Lucie Matějovská, Arnošt Novák, Eliška Rolfová, Veronika Tvardková, Irena Valešová, and Martin Veselý. 2013. Zahrádkové osady: Stíny minulosti nebo záblesky budoucnosti? [Allotment Gardens: Shadow of the Past or a Glimpse of the Future?]. Prague, Czech Republic: Faculty of Humanities, Charles University.

Gotts, Nick and Imre Kovách, eds. 2010. Climate Change and Local Governance: Alternative Approaches to Influencing Household Energy Consumption (A Comparative Study of Five European Regions). Budapest, Hungary: Hungarian Academy of Sciences. Retrieved May 18, 2016 (http://mek.oszk.hu/09300/09355/09355.pdf).

Gray, Leslie, Patricia Guzman, Kathryn Michelle Glowa, and Ann G. Drevno. 2014. "Can Home Gardens Scale Up into Movements for Social Change? The Role of Home Gardens in Providing Food Security and Community Change in San Jose, California." Local Environment 19(2):187-203.

Hiroki, Sayaka, Elena Garnevska, and Sarah McLaren. 2016. "Consumer Perceptions about Local Food in New Zealand, and the Role of Life Cycle-Based Environmental Sustainability." Journal of Agricultural and Environmental Ethics 29(3):479-505.

Hjelmar, Ulf. 2011. "Consumers' Purchase of Organic Food Products. A Matter of Convenience and Reflexive Practices." Appetite 56:336-44.

Jehlička, Petr and Petr Daněk. Forthcoming. "Rendering the Actually Existing Sharing Economy Visible: Home Grown Food and the Pleasure of Sharing." Sociologia Ruralis.

Jehlička, Petr, Tomáš Kostelecký, and Joe Smith. 2013. "Food Self-provisioning in Czechia: Beyond Coping Strategy of the Poor; A Response to Alber and Kohler's 'Informal Food Production in the Enlarged European Union' (2008)." Social Indicator Research $111(1): 219-34$.

Jehlička, Petr and Joe Smith. 2011. "An Unsustainable State: Contrasting Food Practices and State Policies in the Czech Republic." Geoforum 42(3):362-72. 
2012. "Sustainability and the 'Urban Peasant': Rethinking the Cultural Politics of Food Self-provisioning in the Czech Republic." Pp. 78-96 in New Perspectives on Consumer Culture Theory and Research, edited by P. Zahrádka and R. Sedláková. Newcastle upon Tyne, England: Cambridge Scholars.

Katrňák, Tomáš, Martin Kreidl, and Laura Fónadová. 2006. "Trends in Educational Assortative Mating in Central Europe: The Czech Republic, Slovakia, Poland, and Hungary, 1988-2000.” European Sociological Review 22(3):309-22.

Kortright, Robin and Sarah Wakefield. 2011. "Edible Backyards: A Qualitative Study of Household Food Growing and Its Contributions to Food Security." Agriculture and Human Values 28:39-53.

Kovách, Imre. 1994. "Privatization and Family Farms in Central and Eastern Europe." Sociologia Ruralis 34(4):369-82.

Kovách, Imre and Boldizsár Megyesi. 2006. "Local Food Production and Knowledge Dynamics in Rural Sustainable Development." Pp. 24-36 in Local Food Production, NonAgricultural Economies and Knowledge Dynamics in Rural Sustainable Development (the Czech, Hungarian and Polish Cases). Working Papers No. 7 2006/5, edited by I. Kovách and K. Gorlach. Budapest, Hungary: Hungarian Academy of Sciences. Retrieved March 20, 2016 (http://mek.oszk.hu/04000/04024/04024.pdf).

Larder, Nicolette, Kristen Lyons, and Geoff Woolcock. 2014. "Enacting Food Sovereignty: Values and Meanings in the Act of Domestic Food Production in Urban Australia." Local Environment 19(1):56-76.

Lockie, Stewart, Kristen Lyons, Geoffrey Lawrence, and Kerry Mummery. 2002. "Eating 'Green': Motivations behind Organic Food Consumption in Australia." Sociologia Ruralis 42(1):23-40.

Memery, Juliet, Robert Angell, Phil Megicks, and Adam Lindgreen. 2015. "Unpicking Motives to Purchase Locally-Produced Food: Analysis of Direct and Moderation Effects." European Journal of Marketing 49(7 - 8):1207-33.

Metzger, Marc Joris, Robert Gerald Henry Bunce, Rob H. G. Jongman, Caspar A. Mücher, and John W. Watkins. 2005. "A Climatic Stratification of the Environment of Europe." Global Ecology and Biogeography 14(6):549-63.

Morton, Lois Wright, Ella Annette Bitto, Mary Jane Oakland, and Mary Sand. 2008. "Accessing Food Resources: Rural and Urban Patterns of Giving and Getting Food." Agriculture and Human Values 25:107-19.

Niñez, Vera K. 1984. Household Gardens: Theoretical Considerations on an Old Survival Strategy. Potatoes in Food Systems Research Series. Report No. 1. Washington, DC: U.S. Agency for International Development. Retrieved March 10, 2016 (http://pdf.usaid. gov/pdf_docs/PNAAS307.pdf).

Reyes-García, Victoria, Sara Vila, Laura Aceituno-Mata, Laura Calvet-Mir, Teresa Garnatje, Alexandra Jesch, Juan José Lastra, Montserrat Parada, Montserrat Rigat, Joan Vallès, and Manuel Pardo-de-Santayana. 2010. "Gendered Homegardens: A Study in Three Mountain Areas of the Iberian Peninsula." Economic Botany 64(3):235-47.

Rose, Richard and Yevgeniy Tikhomirov. 1993. "Who Grows Food in Russia and Eastern Europe?" Post-Soviet Geography 34(2):111-26.

Schächtele, Katharina and Hans Hertle. 2007. Die $\mathrm{CO}_{2}$ Bilanz des Bürgers: Recherche für ein internetbasiertes Tool zur Erstellung persönlich $\mathrm{CO}_{2}$ Bilanzen $\left[\mathrm{CO}_{2}\right.$ Emissions of the Citizens: Review for the Online Measurement Tool of Personal $\mathrm{CO}_{2}$ Emissions]. Heidelberg, Germany: Umweltbundesamt. Retrieved September 15, 2016 (https://www.umweltbundesamt. de/sites/default/files/medien/publikation/long/3327.pdf).

Schupp, Justin L. and Jeff S. Sharp. 2012. "Exploring the Social Bases of Home Gardening." Agriculture and Human Values 29:93-105.

Schwartz, Christine R. and Robert D. Mare. 2005. "Trends in Educational Assortative Marriage from 1940 to 2003." Demography 42(4):621-46.

Siegrist, Michael, Vivianne H. M. Visschers, and Christina Hartmann. 2015. "Factors Influencing Changes in Sustainability Perception of Various Food Behaviors: Results of a Longitudinal Study." Food Quality and Preference 46:33-39. 
Smith, Joe and Petr Jehlička. 2013. "Quiet Sustainability: Fertile Lessons from Europe's Productive Gardeners." Journal of Rural Studies 32:148-57.

Smith, Vincent M., Robert B. Greene, and Janet Silbernagel. 2013. "The Social and Spatial Dynamics of Community Food Production: A Landscape Approach to Policy and Program Development." Landscape Ecology 28:1415-26.

Sovová, Lucie. 2015. "Self-provisioning, Sustainability and Environmental Consciousness in Brno Allotment Gardens." Sociální Studia 12(3):11-26.

Swain, Nigel. 2001. Traditions of Household Farming and Gardening in Central Europe. Working Paper No. 51. Rural Transition Series. Liverpool, England: University of Liverpool.

Taylor, John R. and Sarah Taylor Lovell. 2013. "Urban Home Food Gardens in the Global North: Research Traditions and Future Directions." Agriculture and Human Values $31(2): 285-305$.

Teitelbaum, Sara and Thomas Beckley. 2006. "Harvested, Hunted and Home Grown: The Prevalence of Self-Provisioning in Rural Canada." Journal of Rural and Community Development 1(2):114-30.

Tho Seeth, Harm, Sergei Chachnov, Alexander Surinov, and Joachim von Braun. 1998. "Russian Poverty: Muddling through Economic Transition with Garden Plots." World Development 26(9):1611-23.

Tobler, Christina, Vivianne H. M. Visschers, Michael Siegrist. 2011. "Eating Green. Consumers' Willingness to Adopt Ecological Food Consumption Behaviors." Appetite 57: 674-82.

Torsello, Davide. 2005. "Neviditelné základy dôvery: Domáca produkcia, práca a výmena na slovenskej dedine [The Invisible Bases of Trust: Household Production, Work and Exchange in a Slovakian Village]." Slovak Ethnology/Slovenský Národopis 2005(1):5-19.

Trnka, M., J. E. Olesen, K. C. Kersebaum, A. O. Skjelvåg, J. Eitzinger, B. Seguin, P. Peltonen-Sainio, R. Rötter, A. Iglesias, S. Orlandini, M. Dubrovský, P. Hlavinka, J. Balek, H. Eckersten, E. Cloppet, P. Calanca, A. Gobin, V. Vučetić, P. Nejedlik, S. Kumar, B. Lalic, A. Mestre, F. Rossi, J. Kozyra, V. Alexandrov, D. Semerádová, and Z. Žalud. 2011. "Agroclimatic Conditions in Europe under Climate Change." Global Change Biology 17(7):2298-318.

United Nations. 2014. "World Urbanization Prospects: The 2014 Revision." CD-ROM. Retrieved April 30, 2016 (http:/ / esa.un.org/unpd/wup/CD-ROM/).

Van der Ploeg, Jan Douwe. 2009. The New Peasantries: Struggles for Autonomy and Sustainability in an Era of Empire and Globalization. London, England: Earthscan.

Vávra, Jan and Miloslav Lapka. 2013. "Size Matters: Climate Change Perception and Carbon Footprint of Czech Households." Culturologia 2(2):18-25.

Vogl, Christian R. and Brigitte Vogl-Lukasser. 2003. "Tradition, Dynamics and Sustainability of Plant Species Composition and Management in Homegardens on Organic and Non-organic Small Scale Farms in Alpine Eastern Tyrol, Austria.” Biological Agriculture and Horticulture: An International Journal for Sustainable Production Systems 21(4): 349-66. 